\title{
Tension Headache
}

National Cancer Institute

\section{Source}

National Cancer Institute. Tension Headache. NCI Thesaurus. Code C117070.

A headache associated with muscle tightness which may radiate to other parts of the body. 